\title{
Services marketing practices in diverse cultures: Canada compared to Qatar
}

\author{
Allam K. Abu Farha \\ Department of Management and Marketing, Qatar University, Doha, Qatar \\ Paul Sergius Koku \\ Department of Marketing, Florida Atlantic University, Boca Raton, Florida, USA \\ Sam O. Al-Kwifi \\ Department of Management and Marketing, Qatar University, Doha, Qatar, and \\ Zafar U. Ahmed \\ Graduate School of Management, University Putra Malaysia, Serdang, Malaysia
}

\begin{abstract}
Purpose - The service marketing literature has traditionally argued that the marketing practices of service firms that operate in diverse cultures should also differ. This paper aims to investigate this argument by examining the marketing practices of service firms in two highly diverse countries "Canada and Qatar" in the context of a contemporary conceptual framework.

Design/methodology/approach - Survey data were collected in both countries using a self-administered questionnaire that was used in previous contemporary marketing practice (CMP) studies. The data analysis was conducted in two stages. First, descriptive statistics were used to determine cross-national differences in the intensity of use of various CMP activities in Qatar compared to Canada. Second, cross-national differences in various combinations of marketing practices were identified using a cluster analysis.

Findings - The results indicate that service firms in both countries have more similarities than differences and that the overall patterns of marketing practices are similar. In addition, the firms' marketing practices reflect aspects of all four marketing approaches rather than just one.

Research limitations/implications - The study was conducted in only two countries, thus generalisability of its findings and conclusions may not be possible.

Practical implications - The results of this study can help marketers to better understand the changing marketing environment and identify new marketing solutions when operating in different environments.

Originality/value - This study enhances the literature on service marketing and expands the application of the CMP framework to a new context that has not been addressed in previous studies.
\end{abstract}

Keywords Relationship marketing, Marketing practices, Globalization, Service organizations, Transactional marketing, Service marketing practices, Relationship marketing

Paper type Research paper

\section{Introduction}

Changes in the marketplace caused by several external forces have led to the resurgence of debate among academics on the nature of marketing practices and their relevance within the contemporary business environment (Baker, 2014; Demangeot et al., 2015). As noted by some academics, one of these forces is the increased presence of ethnic groups which developed culturally diverse markets (Ivanova-Gongne, 2015; Sharma et al., 2015). Service marketing scholars have become interested in the effects of the ensuing cultural diversity on existing marketing practices. Questions such as whether these cultural changes have uniformly affected the services marketing

The current issue and full text archive of this journal is available on Emerald Insight at: www.emeraldinsight.com/0887-6045.htm

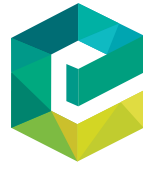

Journal of Services Marketing

33/7 (2019) 771-782

Emerald Publishing Limited [ISSN 0887-6045]

[DOI 10.1108/JSM-02-2018-0062] practices in developed nations and emerging market economies have been raised (Ihtiyar and Ahmad, 2015). However, little research has examined contemporary services marketing practices in different cultures, even when the level of cultural diversity is noticeably high (Sharma et al., 2015).

As the cultural diversity of societies increases, the need for developing successful services marketing practices becomes more challenging (Tam et al., 2016). Some companies have successfully developed those practices. Take for instance Skytrax's best airline award for 2018 (which is considered "the Oscars of the aviation industry"), Air Qatar was ranked at

(C) Allam K. Abu Farha, Paul Sergius Koku, Sam O. Al-Kwifi and Zafar U. Ahmed. Published by Emerald Publishing Limited. This article is published under the Creative Commons Attribution (CC BY 4.0) licence. Anyone may reproduce, distribute, translate and create derivative works of this article (for both commercial and non-commercial purposes), subject to full attribution to the original publication and authors. The full terms of this licence may be seen at http://creativecommons.org/licences/by/4.0/legalcode

Received 8 February 2018

Accepted 10 June 2019 
the top of the list, and Air Canada was selected as the best Airline in North America (Skytrax, 2018). Even though these two airlines are successful service providers, they use different marketing approaches. Air Canada slashes overhead and other comfort elements in order to compete for (price conscious) passengers, while Qatar Airways works to provide the very high standards of service. Air Canada's marketing exchange is primarily based on economic transactions with customer attraction as a key objective. In contrast, Qatar Airways works to create interpersonal relationships which it continually works on improving.

The different success paths taken by Qatar Airways and Air Canada underscore suggestions in the academic marketing literature that the marketing practices of firms operating in different cultures would be fundamentally different (Arnold and Bianchi, 2001; Ivanova-Gongne, 2015; Kirca et al., 2009, Kirca, 2001; Ivanova-Gongne, 2015; Kirca et al., 2009). This literature has been heavily influenced by strong conceptual arguments developed from a general understanding that different cultures would have different market structures, demand patterns and buyer behaviours (Steenkamp, 2001; Usunier and Lee, 2005), which have led to the assumption that the marketing practices of firms in diverse cultures must also be different. However, several scholars have also questioned the relevance of this stream of marketing scholarship for managerial practices in different settings (Coviello et al., 2002; Dadzie et al., 2008). Although some studies have been conducted to improve marketers' understanding of how marketing practices differ from academic literature, such as CMP research (Brodie et al., 2008), other scholars believe that much more empirical research needs to be done to improve our cumulative understanding of contemporary marketing in global markets (Dadzie et al., 2008; Day and Montgomery, 1999). This is especially true for diverse emerging and transitioning economies (Faria and Wensley, 2000).

Accordingly, the first goal of this paper is to determine whether the appearance of culturally diverse markets with an increased emergence of ethnic groups have the same influence on services marketing practices in different cultural settings? In other words, this study seeks to examine the similarities and/or differences in the marketing practices of service firms in two highly diverse cultures, Canada and Qatar, for deeper insight on service strategies. While we acknowledge that service firms employ different marketing practices depending on their context, this study attempts to determine how similar service firms that serve similar markets approach their targets from contrasting angles. We believe that this examination is important because marketing in general includes a range of practices - transactional to relational - that are shaped by different activities that vary considerably from one cultural setting to another (Araujo et al., 2008; Hinson and Dadzie, 2009).

Furthermore, several services marketing scholars have posited that conventional marketing concepts (e.g. the 4Ps) fail to provide the necessary conceptualisation for modelling and managing service firms (Berry, 1995; Grönroos, 1990; Lovelock and Wright, 2001). Many researchers have argued that the nature of the product being offered affects how a firm relates to its market, and have proposed that service organisations benefit from relational marketing (RM) practices (Brodie et al., 2006; Vargo and Lusch, 2008). However, other scholars found that service companies employ pluralistic marketing practices (Brodie et al., 2008). Given these contradictory assertions in the context of the goods-services dichotomy, several researchers have called for further investigations into whether the marketing practices of service firms (firms that sell intangible products) differ from those that provide goods (firms that sell tangible products). Thus, the second research question is how do service firms approach their markets when examined in the context of a more relational (and less traditional) view of marketing in different cultures?

To answer these questions, we employed the contemporary marketing practice (CMP) framework (Coviello et al., 1997) because it is the most developed framework that "emphasises both theoretical development (suggesting a typology) and empirical evidence, eliciting a taxonomy of marketing practices" (Pels, 2010, p. 135). In addition to uncovering the types of profiling that may exist in the two cultures, this paper follows the steps of previous CMP studies (Dadzie et al., 2008; Pels and Brodie, 2004) by using a cluster analysis as a statistical tool to identify common combinations of marketing activities. This approach is the preferred statistical technique for defining groups/objects (Hair et al., 2006) and it is the recommended approach when little or no information is known about the number of categories or the membership of each firm (Fiss, 2007).

This paper contributes to the existing services marketing literature in several ways. First, the study identifies similarities and differences in the marketing practices of two highly diverse countries. Several authors have considered work that provides an empirical basis for universal cross-cultural or cross-national comparisons as an important contribution to marketing literature (Kiss and Danis, 2008) and as a valuable decisionmaking tool for firms involved in international operations (Brodie and Danaher, 2000; Hassi and Storti, 2017). In addition, this paper can help services marketers identify critical issues that are involved in marketing to diverse to ethnic consumers. We argue that identifying such issues is a necessary condition for formulating a viable services marketing strategy. Second, this study explores services marketing practices in a new setting to evaluate whether theories developed using the traditional settings remain valid and whether methods applied in different environments have the same or similar impacts (Berthon et al., 2002). Relatedly, this paper reports findings on a less-researched setting, Qatar, which can be considered representative of other Gulf Cooperation Council countries (Abu Farha and Elbanna, 2018). These findings may complement or improve the predominant management and business models that have been developed using the context of developed markets.

The remainder of this paper is organised as follows. First, we review the extant literature on services marketing practices and address the influence of cultural diversity. We then present the empirical study and research findings on marketing practices across the two countries. The paper concludes with a discussion of the study's findings, implications and future avenues for research.

\section{Literature review}

In this section, we review previous research on marketing practices and justify adopting the transactional marketing/ 
relation marketing (TM/RM) framework in this study. We also explain how cultural diversity could influence services marketing practices.

\section{Services marketing practices}

Several services marketing scholars argued that service firms are expected to emphasise relational marketing in terms of their decisions and actions regarding the market (Gronroos, 1993; Lovelock and Wright, 2001). This argument was supported by the fact that service firms are distinguished from nonservice firms as their offering is considered a service (intangible) rather than a good (tangible). Often, this distinction is made by discussing the intangibility, heterogeneity, inseparability and perishability of the firm's offerings (Sweeney et al., 2011). However, several empirical studies have found that many service firms took a combined approach to marketing practices rather than relational marketing only (Coviello et al., 2006).

As noted above, the existing services marketing literature proposes two major perspectives from which one could understand the different types of marketing practices. Proponents of the first perspective adopt a dichotomous stance, where they distinguish between TM and RM as the opposite ends of a continuum (Grönroos, 1991; Håkansson and Snehota, 1989); they place traditional goods-centric marketing at one end of the continuum and the emerging area of servicecentred marketing at the other end (Vargo and Lusch, 2004). Proponents of the second approach also conceptualise services marketing practices along a continuum, but adopt a more pluralistic view. They consider a broad spectrum of services marketing practices that include:

- Transactional Marketing (TM), database marketing (DM), interaction marketing (IM) and network marketing (NM) (The CMP Group, Coviello et al., 1997).

- Transactional exchanges, value-adding exchanges and collaborative exchanges (Day, 2000).

- Narrow and broad-relationship marketing (Sheth and Parvatiyar, 2000).

While a dichotomous approach is useful in simplifying relationships in the field of service marketing, and makes it easy to understand the market dynamic, it does not capture the diversity of practices that can be found between the two poles (Pels, 2010), which is also essential to a deeper understanding of marketing activities. Hence, this study adopts the pluralistic view and treats services marketing practices as complementary rather than alternative (Arndt, 1979). Furthermore, this study builds on work done by the CMP Group to demonstrate the diversity of services marketing practices across different cultures. The CMP's work was chosen for two main reasons:

1 First, besides being the most developed model, the CMP's work emphasises both theoretical development (suggesting a typology), and empirical evidence eliciting a taxonomy of marketing practices' (Lindgreen et al., 2008);

2 Second, it is supported by extensive empirical work (Coviello et al., 2002; Dadzie et al., 2008).

The CMP's work groups and tests marketing practices in contemporary business environments. It also tests the significance of RM in diverse organisational and environmental settings (Abu Farha, 2016; Brodie et al., 2008; Coviello et al., 2002). Their results challenged the beliefs of service marketing experts who posited that transactional and relational approaches are discrete. Based on an extensive review of previous studies, Coviello et al. (1997) developed a classification scheme containing two themes (relational exchange and management activities) that correspond to nine dimensions that capture the way firms interact with markets. The first five dimensions relate to relational exchange, while the remaining four deal with management activities.

Relational exchange: This dimensional construct was developed by Coviello et al. (1997) to incorporate the transactional and relational properties of "exchange". The authors initially identified seven indicators to measure this dimension. This was later reduced to five indicators, namely: focus of the relational exchange, nature of communication between parties, type of contact, type of exchange and level of formality (Coviello et al., 1997).

Managerial dimension: This theme relates to "how managers use their time, energies, and enthusiasms, as well as the available financial resources" (Coviello et al., 1997, p. 512). It is measured using four dimensions: intent of managerial decisions, focus of managerial decision-making, managerial investment and managerial level of implementation.

The CMP, after a careful analysis, identified four types of marketing practices, which are reviewed below, instead of the two aforementioned themes:

1 Transactional marketing: This type of marketing practice reflects the marketing management school, where the focus is on "attracting and satisfying potential buyers by managing the elements in the marketing mix" (Palmer and Wilson, 2009, p. 172). In this type of marketing, the seller is the actor, the communication is "to" rather than "with" the customer, the goal is to attain new customers and the transaction is short-term sales at arm's length (Coviello et al., 2006).

2 Database marketing: This reflects the tactical part of relationship marketing, whose goal is to retain customers by using technology-based tools. The seller is still the active member and communication is "to" customers (Brodie et al., 2008).

3 Interaction marketing: This type of relationship marketing seeks to develop interpersonal relationships with customers to create cooperative interaction for mutual benefit. It implies face-to-face interaction, which means communication is "with" customers, and the goal is to retain current customers by creating a cooperative mutual benefit (Coviello et al., 1997).

4 Network marketing: This marketing practice carries the elements of interaction marketing, but aims to formulate relationships between firms at different levels to permit coordination of activities between multiple parties to build up the organisation's position in a network of several firmlevel relationships (Coviello et al., 1997).

\section{Culture and services marketing practices}

Culture is complex and therefore difficult to define. Comprehensively, we define culture as the aggregate, common characteristics that shape a group's response to its environment (Hofstede, 1980). The impact of culture on services marketing practices could appear straightforward because it is established 
that cultural norms and values have an impact on the formation of attitudes and preferences (Gelfand et al., 2007). It is therefore accepted that culture has a considerable effect on the decisions and thought processes of managers and their perceptions of managerial issues and concepts (Chikudate, 1997). As such, an organisation's strategic decisions, including its marketing practices, would likely differ from culture to culture (Dadzie et al., 2008).

The existing services marketing literature discusses the importance of culture on marketing practices and examines how marketing strategies that have been effectively applied in certain - mainly Western - countries cannot be directly exported to other cultures. For example, when measures such as RELQUAL (Payan et al., 2010) or customer relationship management (Kumar et al., 2011) are applied in cross-cultural contexts, modifications recognising culture-based differences have been recommended. Evidence also shows that culture affects the process through which resources affect relational outcomes (Ivanova-Gongne, 2015; Rees-Caldwell and Pinnington, 2013).

Indeed, many researchers have identified dimensions along which cultures differ (Clark, 1990; Hofstede, 1980; Inkeles and Levinson, 1997), yet they tend to agree that despite the various labels (Schwartz, 1994) and subtle differences in meaning and culture, individualistic and collectivistic cultures produce distinctly different normative orientations toward establishing and maintaining relationships. This paper builds on Hofstede's framework and examines two culturally diverse countries, one representing an individualistic culture (Canada) and the other a collectivist culture (Qatar).

The impact of culture on marketing decisions has been increasingly reflected in the services marketing literature since Hofstede's groundbreaking work which introduced national cultural dimensions (Hofstede, 1980). Several researchers have argued that national culture is a crucial determinant of a host of organisational and managerial behaviour (Kirca et al., 2009; Nakata and Sivakumar, 2001). These scholars argue that national culture greatly influences thinking patterns of managers and employees and thereby their beliefs about which marketing orientation to adopt (Rothaermel et al., 2006).

\section{Hypothesis development}

Since Hofstede (1980), several marketing scholars have used culture as a general theory to explain differences in marketing management decision-making and market orientation (Ivanova-Gongne, 2015; Kirca et al., 2009; Slater et al., 2011). This line of research has shown the power of culture in explaining the diversity of marketing behaviour. Several scholars have shown that some marketing strategies such as the choice of international marketing strategy (Steenkamp, 2001), channel design (Johnson et al., 1990), market entry decisions (Rothaermel et al., 2006) and product development approaches might be impacted by culture.

According to Hofstede's framework, Qatar is considered a collectivist culture where members of society tend to hold an interdependent view of the self that emphasises connectedness, social context and relationships (Rees-Caldwell and Pinnington, 2013). In a collective culture, tight interpersonal relationships play a central role in business transactions (Dash et al., 2007). Service firms in such cultures need to develop trust on person-to-person basis before engaging in business (Rothaermel et al., 2006). Furthermore, there is a greater emotional interdependence at a personal level. Collectively, these are likely to be the driver for firms in such group-oriented cultures to build commitment and long-term relationships (relational practice) with their customers as buyers prefer dealing with firms that they can trust (Chai et al., 2012). In other words, service firms from collective cultures have a tendency to base their competitiveness on building relationships and maintaining connections with their customers. There are empirical studies that support this idea; for example, Dash et al. (2007) found that buyers in collectivistic cultures prefer banks that stress structural bonding. In the same vein, Abu Farha and Elbanna (2018) found that more than a third of Qatari service firms employed Relational Marketing practices. Furthermore, Kale and McIntyre (1991) argue that firms in collective countries choose relationship partners they consider as friends. On the basis of these studies, one would make the following hypothesis:

H1. Service firms that operate in collectivist cultures are more likely to engage in relational marketing practices (interaction or network).

On the other hand, Canadian firms that operate in an individualistic culture where members tend to hold an independent view of the self that emphasise separateness (Hofstede et al., 1991). Individualist cultures are characterised by a self-orientated and loose interpersonal relationships (Hofstede, 1980). Cultures that maintain individualistic values focus more heavily on transactions and less on the personal relationship (Dash et al., 2007), while firms in self-oriented cultures will probably choose objective performance criteria (Lovelock and Gummesson, 2004). Service firms from individualistic countries prefer impersonal contact with their customers and tend to focus on the product and brand (Rothaermel et al., 2006). Some empirical studies have supported this assertion; for example, Coviello et al. (2006) found that transactional marketing was the predominant practice among small Canadian service firms. In the same vein, Sweeney et al. (2011) found that interaction marketing was the most common practice in professional service firms in developed economies. These findings suggest that:

H2. Service firms that operate in individualistic cultures are more likely to engage in transactional marketing practices (transactional or database).

\section{Methodology}

\section{Measures}

To investigate similarities/differences in the services marketing practices of service firms in Qatar and Canada (two countries identified to have diverse cultures), we employed a structured survey method. We used the first section of the survey to collect general information about the respondents and firms participating in the study. The second section was used to measure the services marketing practices using the CMP's standard questionnaire (The CMP Group, Coviello et al., 1997). The CPM's standard questionnaire contains 36 
questions. Each type of practice (transactional, database, interaction and network) is assigned nine items that are written in a random order to avoid receiving similar responses caused by similarities between subsequent questions (Gerber and Malhotra, 2008; McFarland, 1981).

\section{Data collection and sample}

Canada and Qatar were chosen based on the theoretical reasoning that both countries stand on different angles of Hofstede's (1980) three cultural dimensions that are theoretically linked to relationship development: individualism, power distance and uncertainty avoidance. Both markets are very similar in the sense that consumers in both countries are highly diverse. Take for instance the Canadian population consists of 200 ethnic groups, with 13 surpassing the 1 million mark (National Household Survey, 2013). In Qatar, 88 per cent of the population is comprised of 87 different nationalities (Cheeseman, 2016).

In all, 250 firms in each country were selected from a list of service companies from each country's Chamber of Commerce. To obtain the best representation of the population, the questionnaire was distributed to a wide range of industries within the service sector and included a broad range of firm sizes. We followed the guidelines of Olson et al. (2005) in collecting data from key informants and chose marketing or sales managers as the key informants because they are knowledgeable about their firms' services marketing practices.

The data were gathered between May and November 2016. The respondents were contacted to request an appointment to participate on a voluntary basis. Although only one informant from each firm was asked to complete the questionnaire, respondents were encouraged to consult with others in their organisation if they were unable to respond to any question. The questionnaire was provided in English and Arabic, and the respondents could choose which version they preferred to answer. A back translation technique was used to translate the questionnaire into Arabic and from Arabic into English to ensure that both the English and Arabic versions were identical.

Of the targeted samples, 192 responses were received from Qatar and 148 were received from Canada. Table I shows the descriptive statistics of companies in our sample. Of the Qatari sample, 49 per cent of the organisations were established between 3 and 10 years before the study was conducted. Twenty per cent were less than two years old, and the remainder (30 per cent) were more than 11 years old. Over 18 per cent of the Qatari companies were in the finance sector, about 23 per cent were in the leisure and hospitality sector and 33 per cent were selfidentified as "other". Of these organisations, 57 per cent were jointly owned, 12 per cent were completely foreign-owned and 30 per cent were completely domestically owned. Of the Canadian sample, 63 per cent of the organisations had been in existence for over 10 years. Twenty eight per cent of the firms were in finance, 21 per cent were in leisure and hospitality and 19 per cent were in other service sectors. Of these organisations, 37 per cent were jointly owned, 9 per cent were completely foreignowned and 52 per cent were completely domestically owned.

The Canadian sample did not differ much from the sample from Qatar. Noticeable differences were that the Qatari sample comprised a larger number of younger firms and the Canadian sample comprised more firms that were jointly owned; however, a comparative analysis of the main constructs under
Table I Characteristics of the sample

\begin{tabular}{lcc}
\hline & Qatar $(\boldsymbol{n}=192)$ & Canada $(\boldsymbol{n}=\mathbf{1 4 8})$ \\
\hline Type & 18.8 & 28.4 \\
Finance & 22.9 & 21.6 \\
Leisure and hospitality & 8.3 & 16.2 \\
Health Care & 15.1 & 10.8 \\
Retail \& Wholesale & 1.6 & 4.1 \\
Education & 33.3 & 18.9 \\
Other & & \\
Age & 20.8 & 25.7 \\
Less than 2 years & 49.0 & 10.8 \\
3-10 years & 30.2 & 63.5 \\
Older than 10 years & & \\
Employees & 28.1 & 31.1 \\
20 or less & 41.7 & 27.0 \\
21-100 & 30.2 & 41.9 \\
More than 100 & & \\
Ownership & 30.7 & 52.7 \\
Locally owned & 12.0 & 9.5 \\
Foreign owned & 57.3 & 37.8 \\
Jointly owned & & \\
\hline
\end{tabular}

investigation revealed no significant differences between the two samples. In general, the sample size and characteristics described above for both countries were consistent with previous international studies (Abu Farha, 2016; Coviello et al., 2002). A summary of the sample is provided in Table I below.

\section{Data analysis}

A comparative analysis was performed in two stages. Consistent with CMP's previous work (Coviello et al., 2002), we dealt with the four marketing activity constructs as formative measures, indicating that the traditional validation measures were not relevant and, therefore, would not be applied (Dadzie et al., 2008; Pels and Brodie, 2004). In the first part of the analysis, we calculated indices for the four types of marketing practices based on the nine items of the questionnaire for each practice. The scores of these items were summed and divided by five (a five-point scale was used). Thus, the construct was converted to an index ranging from 0.0 to 1.0 (Coviello et al., 2002).

In the second stage, we followed the CMP group's steps to find correlations among the four constructs (Dadzie et al., 2008). We applied a K-mean cluster analysis to classify the different combinations of marketing activities and compared the services marketing practices (Dadzie et al., 2008). K-mean was chosen because its use in segmentation studies in the literature has been well-received (Andriotis et al., 2008; Boksberger and Laesser, 2009), and many scholars consider it a superior method for optimising within cluster homogeneity and between-cluster heterogeneity (Ketchen and Shook, 1996). The number of clusters varied between one and six, and a three-cluster solution was determined based on the average within-cluster difference criterion (Hair et al., 2006).

We also tested the non-response bias by comparing the mean response of the first and last quartiles of respondents (Armstrong and Overton, 1977). This approach assumes that late 
respondents are more likely to share characteristics with nonrespondents. A comparison of the two groups demonstrated no significant differences in respondents' demographic variables such as years of experience, location and position. Furthermore, no significant differences emerged between these two groups across the variables included in the model, thus mitigating any concerns about non-response bias (Lambert and Harrington, 1990).

\section{Findings}

\section{Incidence of service marketing practices}

Table II shows comparisons of the indices of services marketing practices for both countries. The intensity of transactional marketing ranged from medium to high for Qatari (78 per cent) and Canadian (73 per cent) firms. This shows that the transactional marketing practice is common in both countries. However, the same cannot be said for database marketing because Qatari firms employed it with a medium intensity (48 per cent), while Canadian firms employed database practice with a high intensity (79 per cent). This indicates that database marketing is practised far less in Qatar than in Canada. In terms of interaction marketing, the medium-high indices were employed by both the Qatari (74 per cent) and Canadian firms (87 per cent). Similar results (high intensity) were obtained for network marketing for Qatari (74 per cent) and Canadian (72 per cent) firms.

These results indicate that Qatari and Canadian companies practised transactional and network marketing practices to a similar extent. However, the Canadian companies practise database and network marketing more intensively, while the Qatari firms practise database marketing with less intensity than the Canadian firms and network marketing was at about the same level of intensity as the Canadian firms.

Combinations of business-to-business marketing practices Table III presents the results of the correlations among the four constructs to show which combinations are most evident. The results summarised in Table III show that for both countries, the

Table II Comparison of index values by marketing type (\%)

\begin{tabular}{lcc}
\hline & $\begin{array}{c}\text { Qatar } \\
(\boldsymbol{n}=192)\end{array}$ & $\begin{array}{c}\text { Canada } \\
(\boldsymbol{n}=148)\end{array}$ \\
\hline Transaction marketing & 21.4 & 27.1 \\
Low & 50.0 & 39.1 \\
Medium & 28.6 & 33.8 \\
High & & \\
Database marketing & 52.1 & 21.4 \\
Low & 36.4 & 45.8 \\
Medium & 11.5 & 32.8 \\
High & & \\
Interaction marketing & 26.0 & 14.6 \\
Low & 25.0 & 57.8 \\
Medium & 49.0 & 27.6 \\
High & & \\
Network marketing & 28.1 & 29.7 \\
Low & 55.2 & 28.1 \\
Medium & 16.7 & 42.2 \\
High & &
\end{tabular}

Table III Correlations between indices by country

\begin{tabular}{lclll}
\hline & TM & DM & IM & NM \\
\hline Qatari sample & & & \\
TM & & & \\
DM & 0.264 & & \\
IM & -0.13 & 0.37 & \\
NM & 0.014 & 0.544 & 0.559 \\
Canadian sample & & \\
TM & & & \\
DM & 0.37 & & \\
IM & -0.21 & 0.127 & \\
NM & 0.09 & 0.452 & 0.635 \\
\hline
\end{tabular}

correlation between transactional and database marketing is moderate, while the correlation with interaction and network marketing is low and negative. This supports the findings of previous studies that show that database marketing is perhaps an extension of transactional marketing, while transactional and relational marketing stand on opposite ends of a continuum (Grönroos, 1991). In contrast to the Canadian sample, database marketing has a strong correlation with interaction marketing in the Qatari sample, while in both countries database marketing has a strong correlation with network marketing, which suggests that it can be considered one element in the relational approach. Finally, a strong correlation was found between interaction and network marketing. This relation reflects previous arguments of the IMP group (Håkansson, 1982) that a dyadic relationship established in interaction marketing is considered a micro level of network marketing.

To identify the common combinations of service marketing practices in Qatar and Canada, we applied the K-mean cluster algorithm, following Coviello et al. (2002). The determination of the final figure of clusters depended on the cluster interpretability and homogeneity. A four-cluster solution was found to best identify groups in Qatar and three clusters in Canada, as the agglomeration coefficient per cent age change was the highest at these points (Hair et al., 2006). Table IV shows the cluster analysis results for Qatar and Canada.

To confirm this result, the dendrogram was examined (Ketchen and Shook, 1996). The data indicate that most Canadian companies practise interaction and network marketing practices ( 45 per cent), which can be described as the relational marketing cluster. The second group included companies who practised all four types of marketing practices, which we will call pluralistic marketing ( 35 per cent), and the transactional marketing cluster with 20 per cent. In the Qatari sample, the two largest clusters were the interaction/network cluster (38 per cent) and the pluralistic cluster (31 per cent). This was followed by the transactional marketing cluster (18 per cent), while the smallest group (13 per cent) represented companies that practise low-level marketing. It is noteworthy that this cluster did not show up in the Canadian sample.

Table $\mathrm{V}$ provides an analysis of the chi-square test on three variables (size, age and type of ownership) and shows the effects of these clusters on variables that were not included in the cluster analysis. The results in Table $\mathrm{V}$ show that no significant difference can be attributed to company age ( $\operatorname{sig}=0.076$ ) or type of ownership (sig $=0.009$ ). However, company size affects 
Table IV Cluster analysis results

\begin{tabular}{|c|c|c|c|c|c|}
\hline & TM & IM/NM & Pluralistic & Low Marketing & Mean \\
\hline \multicolumn{6}{|l|}{ Qatari Sample } \\
\hline Transactional & 0.91 & 0.55 & 0.8 & 0.42 & 0.59 \\
\hline Database & 0.49 & 0.44 & 0.76 & 0.48 & 0.56 \\
\hline Interaction & 0.53 & 0.87 & 0.77 & 0.55 & 0.73 \\
\hline Network & 0.5 & 0.69 & 0.8 & 0.61 & 0.7 \\
\hline per cent age of firms & 0.18 & 0.38 & 0.31 & 0.13 & \\
\hline \multicolumn{6}{|l|}{ Canadian sample } \\
\hline Transactional & 0.85 & 0.58 & 0.8 & & 0.74 \\
\hline Database & 0.69 & 0.57 & 0.79 & & 0.68 \\
\hline Interaction & 0.63 & 0.79 & 0.82 & & 0.75 \\
\hline Network & 0.43 & 0.73 & 0.75 & & 0.64 \\
\hline per cent age of firms & 0.20 & 0.45 & 0.35 & & \\
\hline
\end{tabular}

Table V Chi square results

\begin{tabular}{|c|c|c|c|}
\hline & Value & Df & Asymp. Sig. (two-sided) \\
\hline \multicolumn{4}{|l|}{ Age } \\
\hline Pearson Chi-Square & 19.547 & 12 & 0.076 \\
\hline Likelihood Ratio & 23.861 & 12 & 0.021 \\
\hline \multicolumn{4}{|l|}{ Size } \\
\hline Pearson Chi-Square & 17.43 & 12 & 0.069 \\
\hline Likelihood Ratio & 21.541 & 12 & 0.023 \\
\hline \multicolumn{4}{|l|}{ Own } \\
\hline Pearson Chi-Square & 17.202 & 6 & 0.009 \\
\hline Likelihood Ratio & 20.082 & 6 & 0.003 \\
\hline
\end{tabular}

the type of marketing practice adopted. This might be the case because large firms serve large markets and this makes relational activities more difficult and costly to implement.

Table VI presents the types of firms that each cluster represents. The analysis shows that firms that are less than two years old use pluralistic marketing (43 per cent) and relational marketing (31 per cent). Furthermore, local and foreign-owned companies tend to focus on pluralistic marketing. Regarding clustering by firm size, it could be seen that large firms use more transactional marketing (43 per cent), while smaller firms tend to concentrate on pluralistic (37 per cent) and low-level marketing (27 per cent), which was found in the Qatari sample only.

\section{Discussion and implications}

Changes in the global markets as a result of increased migration have led to increased cultural diversity in many nations. Service marketing scholars are curious about the effects of the ensuing cultural diversity on existing marketing practices. Questions such as whether these cultural changes have uniformly affected the marketing practices of service firms in developed nations and emerging market economies have been raised (Dadzie et al., 2008). This paper examined two hypotheses regarding the marketing practices of service firms in two culturally diverse economies, one in an advanced market (Canada) and the other in an emerging market (Qatar).

We hypothesised that service firms operating in individualistic cultures would employ TM practices $(H 1)$; while collectivistic
Table VI Characteristics of the both countries clusters

\begin{tabular}{llccl}
\hline & TM & IM/NM & Pluralistic & Low \\
\hline Age & & & & \\
Less than 2 years & 0.14 & 0.31 & 0.43 & 0.12 \\
3-10 years & 0.17 & 0.27 & 0.37 & 0.2 \\
older than 10 years & 0.21 & 0.29 & 0.47 & 0.03 \\
Own & & & & \\
Totally domestic & 0.06 & 0.21 & 0.4 & 0.32 \\
Jointly owned & 0.21 & 0.08 & 0.34 & 0.37 \\
Foreign owned & 0.4 & 0.13 & 0.44 & 0.03 \\
Size & & & & \\
20 or less & 0.02 & 0.33 & 0.37 & 0.29 \\
21-100 & 0.13 & 0.43 & 0.4 & 0.05 \\
over 100 & 0.43 & 0.15 & 0.32 & 0.10 \\
\hline
\end{tabular}

culture firms engage in RM practices (H2). The results offer mixed support for these hypotheses: while some support is found for the expected differences, several similarities are also identified. Next, we discuss the findings and their theoretical implications.

The combined results of the study show some support for differences in services marketing practices between cultures. Qatari service firms placed less emphasis on database marketing practice and more emphasis on interaction marketing with faceto-face interaction. In addition, while both countries employ interaction marketing, the use of it in Qatar is different from that in Canada, where the trend is toward supporting the interaction with e-business tools. Furthermore, the Qatari sample contained a cluster of low-level marketing activity that did not appear in the Canadian sample. Finally, the Qatari sample showed that the companies only practised relational marketing alongside transactional marketing; this could be an indication that these companies still consider relational marketing an "addition to" rather than "alternative option for" marketing. In summary, these findings imply that marketing in individualistic cultures is different from marketing in collectivistic cultures and should be recognised as such in research and education. This argument supports most of the existing literature (Nakata and Sivakumar, 2001; Rothaermel et al., 2006; Steenkamp, 2001). However, further analysis, however, shows that there are more similarities than differences across the two countries. 
Service firms in individualistic and collectivistic cultures (Canada and Qatar in this study), share several commonalities across the two dimensions of marketing practices, such as focus, formality and resource investment. These findings contradict the marketing literature that has consistently argued that different cultures would have different marketing styles. More importantly, the results show that firms in both cultures simultaneously practise traditional and more relational views of marketing. These are done along with the development and management of personal relationships with individual customers (interaction marketing) and efforts to position the firm in a net of various market relationships (network marketing). Thus, both the transactional and relational paradigms are relevant in contemporary marketing, regardless of culture. Therefore, these empirical findings support the argument of Sharma et al. (2015) that changes in the populations of these markets seem to compel the creation of uniformity in marketing practices.

Overall, this paper enriches our understanding of service firms marketing practices in culturally diverse environments. While diverse cultures may differ in market structure, demand patterns and buyer behaviours, this paper argues that the traditional divide between the marketing practices of individualistic and collectivistic cultures is oversimplified in a contemporary environment. Hence, the main implications of this paper are as follows. First, it is important to recognise that while services marketing practices in ethnically diverse cultures are distinctive in certain aspects, they are not fundamentally different from each other. Relatedly, it is important to acknowledge both the similarities and differences in services marketing practices across cultures, including when and why different approaches to marketing are practised, how multiple approaches can be practised simultaneously and how these practices might be influenced by other characteristics. Second, as societies are becoming more diverse, theoretical frameworks must also evolve to reflect new developments in practice and research. In addition, a better understanding of contemporary services marketing practices and theoretical frameworks should include a full spectrum of marketing approaches and not rely solely on transactional or relational paradigms as a conceptual base.

\section{Managerial implications}

This study has several managerial implications. First, it demonstrates the different marketing approaches that service firms can employ in markets of diverse cultures. These results can also help marketers to examine critical issues as well as their perspectives on marketing to ethnic consumers. The existence of multiple market approaches implies that not only is there "more than one way to do things right", but also that the service sector is becoming complex, and different firms might choose different approaches to reach their goals.

This study also shows that service firms from emerging countries should be cautious when deciding which marketing practices to adopt because part of the international benchmarks found in developed countries such as Canada might be irrelevant in their local (host) markets. We found this to be most true in the case of database marketing. Therefore, investing in database technology at this time should not be a top priority for Qatari firms that have limited resources.
The results of interaction marketing activities show some parallel implications. Service firms from an emerging economy should emphasise the use of interaction marketing because of cultural reasons and because of low competition. Furthermore, the results of this study show the importance of interaction and a networking approach as integral parts of doing business with different ethnic groups. Finally, the findings implicitly suggest that most emerging service firms have a narrow focus, which can be attributed to lack of competitive pressure, organisational culture and governmental control. Under these circumstances, the appropriate practices adopted by international service firms that work in emerging markets cannot be asserted with confidence until the influence of other environmental factors has been considered.

\section{Limitations and future research}

Insightful as the results of this study are, there are still limitations that could be addressed by further studies. First, we aimed to determine which service marketing practices have been adopted in each cultural setting rather than the reasons for such adoptions. Future work should explore why service firms chose to adopt one practice over another while considering internal and external factors. This study also focussed on service firms with different offerings; however, it would be worth to study service firms with the same offerings. Furthermore, because the study was restricted samples from only two countries, the generalisability of the findings and conclusions is limited. Therefore, future work should replicate the study in other markets to determine the generalisability of the framework. A further limitation of the study is the use of a cluster analysis to compare marketing practices; future studies should consider using other techniques such as hierarchical linear modelling that will allow for an analysis of the data at different levels. As an analytical technique, hierarchical linear modelling would enable researchers to understand how culture influences different marketing activities (Raudenbush and Bryk, 2002).

Although this study examined how firms attempt to reach consumers with diverse backgrounds, we were unable explore the unique contributions of each factor examined, possible interactions among these factors, or the effectiveness of each marketing practice. To obtain further insights, future research should take a management perspective to assess the effectiveness and perceived value of each practice and extend the study beyond a two-country focus to include different marketing settings or nations using comparative research. Future research could also examine when and why the various aspects of transactional marketing and relational marketing are applied. Finally, a future study that replicates this study with multinational companies from emerging countries that have achieved considerable global performance and compares their marketing practices with similar companies in developed countries could provide deeper insights.

\section{References}

Abu Farha, A. (2016), "Matching organizational frame of reference and business strategy with contemporary marketing practices: evidence from Arab world", International fournal of Emerging Markets, Vol. 11 No. 4, pp. 533-549. 
Abu Farha, A. and Elbanna, S. (2018), "Do different marketing practices pre-suppose different frames of reference? An exploratory study", Fournal of Business $\mathcal{E}$ Industrial Marketing, Vol. 33 No. 3, pp. 337-352.

Araujo, L., Kjellberg, H. and Spencer, R. (2008), “Market practices and forms: introduction to the special issue", Marketing Theory, Vol. 8 No. 1, pp. 5-14.

Armstrong, J.S. and Overton, T.S. (1977), "Estimating nonresponse bias in mail surveys", Fournal of Marketing Research, Vol. 14 No. 3, pp. 396-402.

Arndt, J. (1979), "Toward a concept of domesticated markets", fournal of Marketing, Vol. 43 No. 4, pp. 69-75.

Arnold, K.A. and Bianchi, C. (2001), "Relationship marketing, gender, and culture: implications for consumer behavior", ACR North American Advances, Vol. 1.

Baker, M.J. (2014), Marketing Strategy and Management, Macmillan International Higher Education, New York, NY.

Berry, L.L. (1995), "Relationship marketing of servicesgrowing interest, emerging perspectives", fournal of the Academy of Marketing Science, Vol. 23 No. 4, pp. 236-245.

Berthon, P., Pitt, L., Ewing, M. and Carr, C.L. (2002), "Potential research space in MIS: a framework for envisioning and evaluating research replication, extension, and generation", Information Systems Research, Vol. 13 No. 4, pp. 416-427.

Brodie, R.J. and Danaher, P.J. (2000), "Building models for marketing decisions: improving empirical procedures", International fournal of Research in Marketing, Vol. 17 Nos 2/3, pp. 135-139.

Brodie, R., Coviello, N. and Winklhofer, H. (2008), "Contemporary marketing practices research program: a review of the first decade", fournal of Business E Industrial Marketing, Vol. 23 No. 2, pp. 84-94.

Brodie, R., Pels, J. and Saren, M. (2006), "From Goods-Toward Service-Centered marketing", in Lusch, R.F. and Vargo, S.L. (Eds), The Service-Dominant Logic of Marketing: Dialog, Debate, and Direction, ME Sharpe, New York, NY, pp. 307-319.

Chai, J.C.Y., Deans, K.R. and Biggemann, S. (2012), "The influence of acculturation on consumer relational bonding in banking relationships", fournal of Strategic Marketing, Vol. 20 No. 5, pp. 393-410.

Cheeseman, J. (2016), "Food security in the face of salinity, drought, climate change, and population growth", Halophytes for Food Security in Dry Lands, Elsevier, Amsterdam pp. 111-123.

Chikudate, N. (1997), "Exploring the life-world of organizations by linguistic oriented phenomenology in Sub-cultural analysis of organizations: a comparison between Japanese and US banks", MIR: Management International Review, Vol. 1, pp. 169-183.

Coviello, N., Brodie, R. and Munro, H. (1997), "Understanding contemporary marketing: development of a classification scheme", fournal of Marketing Management, Vol. 13 No. 6, pp. 501-522.

Coviello, N.E., Winklhofer, H. and Hamilton, K. (2006), "Marketing practices and performance of small service firms: an examination in the tourism accommodation sector", Fournal of Service Research, Vol. 9 No. 1, pp. 38-58.

Coviello, N.E., Brodie, R.J., Danaher, P.J. and Johnston, W.J. (2002), "How firms relate to their markets: an empirical examination of contemporary marketing practices", fournal of Marketing, Vol. 66 No. 3, pp. 33-46.

Dadzie, K.Q., Johnston, W.J. and Pels, J. (2008), "Business-tobusiness marketing practices in West Africa, Argentina and the United States", Fournal of Business $\mathcal{E}$ Industrial Marketing, Vol. 23 No. 2, pp. 115-123.

Dash, S., Bruning, E. and Guin, K.K. (2007), “Antecedents of long-term buyer-seller relationships: a cross cultural integration", Academy of Marketing Science Review, Vol. 1.

Day, G. (2000), "Managing market relationships", Fournal of the Academy of Marketing Science, Vol. 28 No. 1, pp. 24-30.

Day, G.S. and Montgomery, D.B. (1999), "Charting new directions for marketing", fournal of Marketing, Vol. 63 No. 4, pp. 3-13.

Demangeot, C., Broderick, A.J. and Craig, C.S. (2015), "Multicultural marketplaces: new territory for international marketing and consumer research", International Marketing Review, Vol. 32 No. 2, pp. 118-140.

Faria, A. and Wensley, R. (2000), "Marketing management within networks: revelations about the research process and cultural specificity as prospects for reconciliation between practice and academe", Paper presented at the Marketing in a Global Economy, The International Marketing Educators' Conference, American Marketing Association, New York, NY.

Gelfand, M.J., Erez, M. and Aycan, Z. (2007), "Cross-cultural organizational behavior", Annual Review of Psychology, Vol. 58 No. 1, pp. 479-514.

Gerber, A.S. and Malhotra, N. (2008), "Publication bias in empirical sociological research: do arbitrary significance levels distort published results?”, Sociological Methods $\mathbb{E}$ Research, Vol. 37 No. 1, pp. 3-30.

Grönroos, C. (1990), Service Management and Marketing: managing the Moments of Truth in Service Competition, Lexington Books, Lexington.

Grönroos, C. (1991), "The marketing strategy continuum: towards a marketing concept for the 1990s", Management Decsion, Vol. 29 No. 1.

Gronroos, C. (1993), "A service quality model and its marketing implications", European fournal of Marketing, Vol. 18 No. 4, pp. 36-44.

Hair, J., Anderson, R., Tatham, R. and William, C. (2006), Multivariate Data Analysis, 6 ed., Prentice Hall, Upper Saddle River.

Håkansson, H. (1982), International Marketing and Purchasing of Industrial Goods: An Interaction Approach, Wiley Chichester, Chichester.

Håkansson, H. and Snehota, I. (1989), "No business is an island: the network concept of business strategy", Scandinavian Fournal of Management, Vol. 5 No. 3, pp. 187-200.

Hassi, A. and Storti, G. (2017), "Interplay between the convoluting forces of culture and globalization", fournal for Global Business Advancement, Vol. 10 No. 3, pp. 261-280.

Hinson, R. and Dadzie, K. (2009), "The influence of organizational environment on contemporary marketing practices (CMP) in Ghana: at Est of the miles and snow strategic typology".

Hofstede, G. (1980), Culture's Consequences: International Differences in Work Related Values, Sage, London.

Hofstede, G., Hofstede, G.J. and Minkov, M. (1991), Cultures and Organizations, McGraw-Hill, London. 
Ihtiyar, A. and Ahmad, F.S. (2015), "The impact of intercultural communication competence on service quality and customer satisfaction", Services Marketing Quarterly, Vol. 36 No. 2, pp. 136-152.

Inkeles, A. and Levinson, D.J. (1997), Cational Character: A Psycho-Social Perspective, Transaction Publishers, New Jersey.

Ivanova-Gongne, M. (2015), "Culture in business relationship interaction: an individual perspective", fournal of Business $\mathcal{E}$ Industrial Marketing, Vol. 30 No. 5, pp. 608-615.

Johnson, J.L., Sakano, T. and Onzo, N. (1990), "Behavioral relations in across-culture distribution systems: influence, control and conflict in US Japanese marketing channels", fournal of International Business Studies, Vol. 21 No. 4, pp. 639-655.

Kale, S.H. and McIntyre, R.P. (1991), "Distribution channel relationships in diverse cultures", International Marketing Review, Vol. 8 No. 3.

Ketchen, D.J. and Shook, C.L. (1996), "The application of cluster analysis in strategic management research: an analysis and critique", Strategic Management fournal, Vol. 17 No. 6, pp. 441-458.

Kirca, S. (2001), “Turkish women's magazines: the popular meets the political", Paper presented at the Women's studies international forum.

Kirca, A.H., Cavusgil, S.T. and Hult, G.T.M. (2009), "The effects of national culture on market orientation: conceptual framework and research propositions", International Business Review, Vol. 18 No. 2, pp. 111-118.

Kiss, A.N. and Danis, W.M. (2008), "Country institutional context, social networks, and new venture internationalization speed", European Management fournal, Vol. 26 No. 6, pp. 388-399.

Kumar, V., Sriram, S., Luo, A. and Chintagunta, P.K. (2011), "Assessing the effect of marketing investments in a business marketing context", Marketing Science, Vol. 30 No. 5, pp. 924-940.

Lambert, D.M. and Harrington, T.C. (1990), "Measuring nonresponse bias in customer service mail surveys", fournal of Business Logistics, Vol. 11 No. 2, p. 5.

Lindgreen, A., Palmer, R., Wetzels, M. and Antioco, M. (2008), "Do different marketing practices require different leadership styles? An exploratory study", Fournal of Business E Industrial Marketing, Vol. 24 No. 1, pp. 14-26.

Lovelock, C. and Gummesson, E. (2004), "Whither services marketing? in search of a new paradigm and fresh perspectives", Fournal of Service Research, Vol. 7 No. 1, pp. 20-41.

Lovelock, C. and Wright, L. (2001), Principles of Service Marketing and Management, Prentice Hall, New York, NY.

McFarland, S.G. (1981), "Effects of question order on survey responses", Public Opinion Quarterly, Vol. 45 No. 2, pp. 208-215.

Nakata, C. and Sivakumar, K. (2001), "Instituting the marketing concept in a multinational setting: the role of national culture", fournal of the Academy of Marketing Science, Vol. 29 No. 3, p. 255.

Olson, E.M., Slater, S.F. and Hult, G.T.M. (2005), "The performance implications of fit among business strategy, marketing organization structure, and strategic behavior", Fournal of Marketing, Vol. 69 No. 3, pp. 49-65.
Palmer, R. and Wilson, H. (2009), “An exploratory case study analysis of contemporary marketing practices", fournal of Strategic Marketing, Vol. 17 No. 2, pp. 169-187.

Payan, J.M., Svensson, G., Awuah, G., Andersson, S. and Hair, J. (2010), "A "cross-cultural RELQUAL-scale" in supplier-distributor relationships of Sweden and the USA", International Marketing Review, Vol. 27 No. 5, pp. 541-561.

Pels, J. (2010), "How do managers understand the environment and how does it relate to the choice of a marketing practice?", (Ph.D.), University of Leicester.

Pels, J. and Brodie, R.J. (2004), "Profiling marketing practice in an emerging economy", Fournal of Global Marketing, Vol. 17 No. 1, pp. 67-91.

Raudenbush, S.W. and Bryk, A.S. (2002), Hierarchical Linear Models: Applications and Data Analysis Methods, Sage, New York, NY, Vol. 1.

Rees-Caldwell, K. and Pinnington, A.H. (2013), "National culture differences in project management: comparing British and Arab project managers' perceptions of different planning areas", International fournal of Project Management, Vol. 31 No. 2, pp. 212-227.

Rothaermel, F.T., Kotha, S. and Steensma, H.K. (2006), "International market entry by US internet firms: an empirical analysis of country risk, national culture, and market size", fournal of Management, Vol. 32 No. 1, pp. 56-82.

Schwartz, S.H. (1994), Beyond Individualism/Collectivism: New Cultural Dimensions of Values, Sage Publications, New York, NY.

Sharma, P., Tam, J.L. and Kim, N. (2015), "Service role and outcome as moderators in intercultural service encounters", Fournal of Service Management, Vol. 26 No. 1, pp. 137-155.

Sheth, J. and Parvatiyar, A. (2000), Handbook of Relationship Marketing, Sage Publications, Thousand Oaks.

Skytrax (2018), "Skytrax's annual world's best 100 airline".

Slater, S.F., Olson, E.M. and Finnegan, C. (2011), "Business strategy, marketing organization culture, and performance", Marketing Letters, Vol. 22 No. 3, pp. 227-242.

Steenkamp, J.-B.E. (2001), "The role of national culture in international marketing research", International Marketing Review, Vol. 18 No. 1, pp. 30-44.

Sweeney, J.C., Soutar, G.N. and McColl-Kennedy, J.R. (2011), "The marketing practices-performance relationship in professional service firms", fournal of Service Management, Vol. 22 No. 3, pp. 292-316.

Tam, J.L., Sharma, P. and Kim, N. (2016), "Attribution of success and failure in intercultural service encounters: the moderating role of personal cultural orientations", fournal of Services Marketing, Vol. 30 No. 6, pp. 643-658.

Usunier, J.C. and Lee, J. (2005), Marketing across Cultures, Prentice Hall, New York, NY.

Vargo, S. and Lusch, R. (2004), "Evolving to a new dominant logic for marketing", fournal of Marketing, Vol. 68 No. 1, pp. 1-17.

Vargo, S. and Lusch, R. (2008), "Service-dominant logic: continuing the evolution", Fournal of the Academy of Marketing Science, Vol. 36 No. 1, pp. 1-10. 


\section{Appendix. CMP standard questionnaire}

\begin{tabular}{|c|c|c|c|c|c|}
\hline 1) Our marketing activities are intended to: & Never & & & ways & NA \\
\hline attract new customers & 1 & 3 & 4 & 5 & 6 \\
\hline retain existing customers & 2 & 3 & 4 & 5 & 6 \\
\hline develop cooperative relationships with our customers & 1 & 3 & 4 & 5 & 6 \\
\hline $\begin{array}{l}\text { d) coordinate activities between ourselves, customers, and other } \\
\text { parties in our wider marketing system (e.g. key suppliers, } \\
\text { service providers and other organisations with which we } \\
\text { interact through our marketing activities) }\end{array}$ & 1 & 3 & 4 & 5 & 6 \\
\hline
\end{tabular}

\begin{tabular}{|c|c|c|c|c|c|}
\hline $\begin{array}{l}\text { 2) Our Marketing planning is focused on issues related } \\
\text { to: }\end{array}$ & Never & & \multicolumn{2}{|c|}{ always } & NA \\
\hline our product/brand/service offering & 1 & 3 & 4 & 5 & 6 \\
\hline customers in our market(s) in addition to our offer & 1 & 3 & 4 & 5 & 6 \\
\hline $\begin{array}{l}\text { c) one-to-one relationships with customers in our market(s), or } \\
\text { individuals in organisations we deal with }\end{array}$ & 1 & 3 & 4 & 5 & 6 \\
\hline $\begin{array}{l}\text { e) the network of relationships between individuals and } \\
\text { organisations in our wider marketing system }\end{array}$ & 1 & 3 & 4 & 5 & 6 \\
\hline
\end{tabular}

\begin{tabular}{|c|c|c|c|c|c|c|}
\hline 3) When dealing with our market(s), our purpose is to: & & & & & & NA \\
\hline $\begin{array}{l}\text { a) generate a profit or other "financial" measure(s) of performance } \\
\text { (monetary transaction) }\end{array}$ & 1 & 2 & 3 & 4 & 5 & 6 \\
\hline $\begin{array}{l}\text { b) acquire customer information for our database in addition to } \\
\text { financial/monetary transactions }\end{array}$ & 1 & 2 & 3 & 4 & 5 & 6 \\
\hline c) build a long-term relationship with a specific customer(s) & 1 & 2 & 3 & 4 & 5 & 6 \\
\hline $\begin{array}{l}\text { d) form relationships with a number of organisations in our } \\
\text { market(s) or wider marketing system }\end{array}$ & 1 & 2 & 3 & 4 & 5 & 6 \\
\hline
\end{tabular}

\begin{tabular}{|c|c|c|c|c|c|}
\hline $\begin{array}{l}\text { 4) Our organisation's contact with our primary customers } \\
\text { is: }\end{array}$ & Never & & aln & & NA \\
\hline $\begin{array}{l}\text { a) arms-length, impersonal with no individualised or personal } \\
\text { contact }\end{array}$ & 1 & 3 & & 5 & 6 \\
\hline somewhat personalised (e.g. by direct mail) & 2 & 3 & 4 & $\mathbf{5}$ & 6 \\
\hline $\begin{array}{l}\text { c) interpersonal (e.g. involving one-to-one interaction between } \\
\text { people) }\end{array}$ & 2 & 3 & 4 & 5 & 6 \\
\hline $\begin{array}{l}\text { d) from impersonal to interpersonal across firms in the broader } \\
\text { network }\end{array}$ & 1 & 3 & 4 & $\mathbf{5}$ & 6 \\
\hline
\end{tabular}

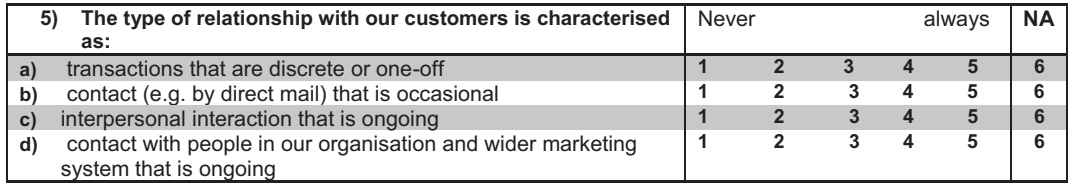

\begin{tabular}{|c|c|c|c|c|c|}
\hline $\begin{array}{l}\text { 6) Our marketing resources (i.e. people, time and money) } \\
\text { are invested in: }\end{array}$ & Never & & \multicolumn{2}{|c|}{ always } & NA \\
\hline $\begin{array}{l}\text { a) product, promotion, price, and distribution activities (or some } \\
\text { combination of }\end{array}$ & 1 & 3 & 4 & 5 & 6 \\
\hline $\begin{array}{l}\text { b) database technology to improve communication with our } \\
\text { customers }\end{array}$ & 1 & 3 & 4 & 5 & 6 \\
\hline $\begin{array}{l}\text { c) establishing and building personal relationships with individual } \\
\text { customers }\end{array}$ & 1 & 3 & 4 & 5 & 6 \\
\hline $\begin{array}{l}\text { developing our organisation's network relationships within our } \\
\text { market(s) or wider marketing system }\end{array}$ & 1 & 3 & 4 & 5 & 6 \\
\hline
\end{tabular}

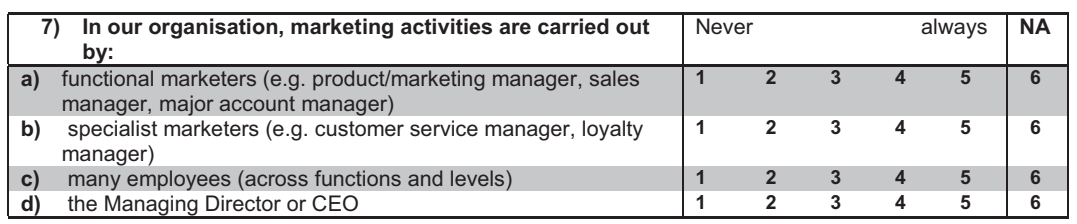

\begin{tabular}{|l|lllc|c|c|}
\hline 8) Our marketing communication involves: & Never & & always & NA \\
\hline a) our organisation communicating to the mass market & $\mathbf{1}$ & $\mathbf{2}$ & $\mathbf{3}$ & $\mathbf{4}$ & $\mathbf{5}$ & $\mathbf{6}$ \\
b) $\begin{array}{l}\text { our organisation targeting a specifically identified segment(s) } \\
\text { or customer(s) }\end{array}$ & $\mathbf{1}$ & $\mathbf{2}$ & $\mathbf{3}$ & $\mathbf{4}$ & $\mathbf{5}$ & $\mathbf{6}$ \\
$\begin{array}{l}\text { individuals at various levels in our organisation personally } \\
\text { interacting with their individual customers }\end{array}$ & $\mathbf{1}$ & $\mathbf{2}$ & $\mathbf{3}$ & $\mathbf{4}$ & $\mathbf{5}$ & $\mathbf{6}$ \\
$\begin{array}{l}\text { d) } \\
\text { senior managers networking with other managers from a } \\
\text { variety of organisations in our market(s) or wider marketing } \\
\text { system }\end{array}$ & $\mathbf{1}$ & $\mathbf{2}$ & $\mathbf{3}$ & $\mathbf{4}$ & $\mathbf{5}$ & $\mathbf{6}$ \\
\hline
\end{tabular}

(continued) 


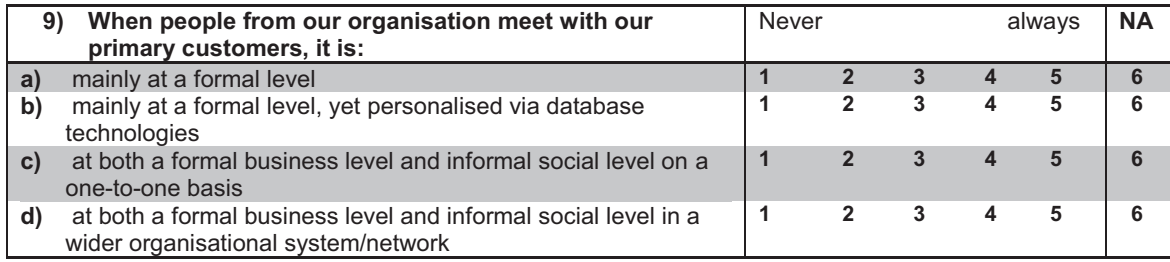

\begin{tabular}{|c|c|c|c|c|c|c|}
\hline $\begin{array}{l}\text { 10) Overall, our organisation's general approach to our } \\
\text { primary customers involves: }\end{array}$ & & & & & & NA \\
\hline $\begin{array}{l}\text { a) Managing the marketing mix to attract and satisfy customers in } \\
\text { a broad market or specific segment. }\end{array}$ & 1 & 2 & 3 & 4 & 5 & 6 \\
\hline $\begin{array}{l}\text { b) mainly at a formal level, yet personalised via database } \\
\text { technologies }\end{array}$ & 1 & 2 & 3 & 4 & 5 & 6 \\
\hline $\begin{array}{l}\text { c) at both a formal business level and informal social level on a } \\
\text { one-to-one basis }\end{array}$ & 1 & 2 & 3 & 4 & 5 & 6 \\
\hline $\begin{array}{l}\text { d) at both a formal business level and informal social level in a } \\
\text { wider organisational system/network }\end{array}$ & 1 & 2 & 3 & 4 & 5 & 6 \\
\hline
\end{tabular}

\section{Corresponding author}

Allam K. Abu Farha can be contacted at: afarha@qu.edu.qa

For instructions on how to order reprints of this article, please visit our website:

www.emeraldgrouppublishing.com/licensing/reprints.htm

Or contact us for further details: permissions@emeraldinsight.com 